\title{
INTEGRAL FORMULA FOR THE DETERMINATION OF PRICE VARIATIONS IN PUBLIC CONTRACTS OF ROAD WORKS
}

\author{
Eddie Enzo Aronés Barbarán \\ National University Federico Villarreal, (Perú). \\ E-mail: fkaseng@unfv.edu.pe ORCID: https://orcid.org/0000-0003-1157-5603 \\ Freddy Lizardo Kaseng Solis \\ National University Federico Villarreal, (Perú). \\ E-mail: fkaseng@unfv.edu.pe ORCID: https:// orcid.org/0000-0002-2878-9053
}

Giro Rodriguez Rodriguez

National University Mayor de San Marcos, (Perú).

E-mail: crodriguezro@unmsm.edu.pe ORCID: https://orcid.org/0000-0003-2112-1349

Recepción: 20/04/2020 Aceptación: 16/06/2020 Publicación: 24/08/2020

\section{Citación sugerida:}

Aronés, E.E., Kaseng, F.L., y Rodriguez, G. (2020). Integral formula for the determination of price variations in public contracts of road works. 3C Empresa. Investigación y pensamiento crítico, 9(3), 97-107. https://doi. org/10.17993/3cemp.2020.090343.97-107 


\section{ABSTRACT}

The objective of the research is to generate a new formula to determine the variation in prices in a public works contract that allows the financial balance of the counterparts. The methodology for calculating and adjusting the price variation in public works contracts is given as a function of the $\mathrm{K}$ factor, which is a number that comes from the calculation of polynomial formulas whose theoretical basis lies in the price indices, which are established in a legal framework of mandatory use of the polynomial formula to determine the $\mathrm{K}$ factor, with eight monomials in the budget and the quantity of supplies that exceeds one hundred. It is considered a subjective margin since its elaboration depends on the discretion of the one who elaborates on the polynomial formula. The investigation questions the procedure established by the state regulations for the calculation of the polynomial formula and shows the margin of error that exists between the value obtained by the method set for regulations and that obtained using the entries of the work budget. The result shows the positive variation in inputs, and the prices have increased, with adjustments paid in the contracts with the benefit of contractors.

\section{KEYWORDS}

Readjustment of prices, Polynomial formula, Variations, Index numbers, Price index, Contracts. 


\section{INTRODUCTION}

To regulate the procedure for calculating adjustments, in 1979, DS No. 11-79-VC (Vice-Ministry of Construction, 1979) was published, where it is established that it will be calculated based on the $\mathrm{K}$ factor resulting from an expression Mathematics that considers the incidence of materials, this expression is called polynomial formula. $\mathrm{K}$ is a number that comes from the calculation of polynomial formulas, whose theoretical basis lies in the price indices (Muñoz, 2004).

The particularity of this polynomial formula is that it considers only a maximum of eight inputs, the most representative in terms of costs, regardless of the complexity of the work or budget. It is necessary to mention that the simplest work has more than one hundred inputs. That is, to date, adjustments are paid with a polynomial formula that only considers a reduced fraction of all the inputs of a public works budget, so classification is important (Soto, 2020).

The current methodology of the polynomial formula for calculating the K factor, which restricts only eight monomials regardless of the complexity of a road work, calls into question the representation of the variation in the prices of the budget estimated by $\mathrm{K}$.

This situation would be leading to an overestimation or underestimation of the budget adjustment (Sanchez, 2020), thus affecting the economic balance between the parties. In the present research work, the analysis of a sample of two polynomial formulas of road works contracts is performed (Huapaya, 2020), calculating the $\mathrm{K}$ factor using all the inputs contained in the technical file. The differences between the $\mathrm{K}$ factors established by each method have been made and the margin of error that exists between both methods has been determined (Levy, 2020).

\section{MATERIAL AND METHODS}

The type of research type is applied, prospective, comparative, and correlational since two variables were related. The factor $\mathrm{K}$ obtained by the established polynomial formula and the factor $\mathrm{K}$ obtained 
from a polynomial formula considering all the inputs. It is predictive of using inferential statistics to corroborate the calculations. The design applied for the development of this thesis is oriented to the study and analysis of the variables that are the subject of our research.

The research design evaluates multiple variables reflected in the unified indices have been manipulated, which have allowed determining the $\mathrm{K}$ factors both by the current polynomial formula and by using all the inputs, proposed in the research.

The source of the data corresponds to the road works contracts of the last five years. The budget, the list of inputs, the execution schedule, and its polynomial formula have been used as the base material for these contracts.

The technical files of road works carried out by the Special Project of Decentralized Transport - PVD of the Ministry of Transport have been considered, to which the probabilistic sampling was applied to the technical files with the same possibility of being chosen. The level of confidence that has been assumed is $95 \%$.

The techniques used for the research will be:

- Documentary review: this technique was used to obtain information through the rules, books, theses, manuals, regulations, directives, and other information.

- Documentary analysis: the technical files of the works contracted by the Ministry of Transport and Communications were analyzed.

- For the management of data such as budgets, unit price analysis, input relationship, preliminary grouping, etc., Excel spreadsheets were used.

Different statistical techniques and tools were used, such as:

- Verification of data normality. 
- Correlation analysis.

- Regression analysis.

- Data visualization.

- Monte Carlo simulation to measure approximate risk.

The MS Office and SPSS programs were used to process and analyze the data.

The research was carried out in the city of Lima with data from public road works, and the methodology process, to determine the $\mathrm{K}$ factor, index numbers, and price indices, is showed in Figure 1.

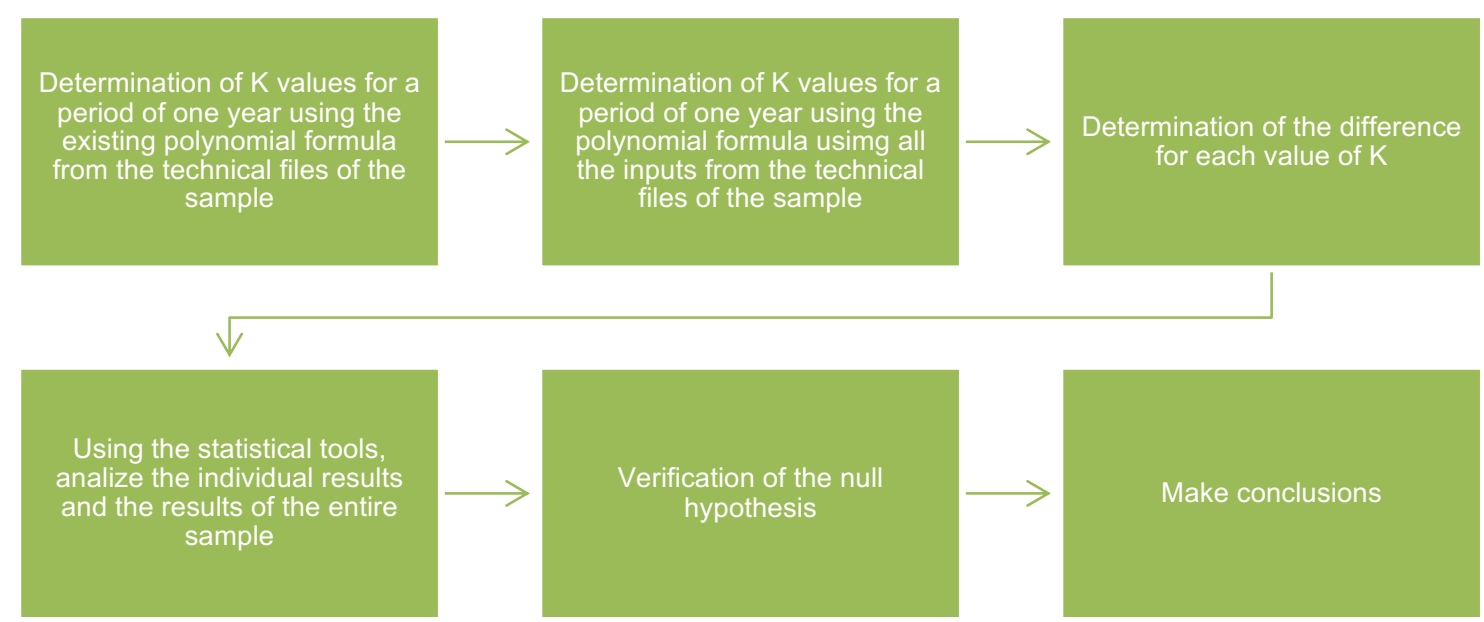

Figure 1. Methodology for determining $\mathrm{K}$ factor differences.

\section{RESULTS}

The analysis of two polynomial formulas of two public road works contracts that to date have been concluded and settled has been carried out. 
The general information of the two works (Case 1 and Case 2) are:

\section{Case 1:}

$$
\begin{gathered}
K=0.085(\mathrm{Mr} / \mathrm{Mo})+0.054(\text { FAMr } / \text { FAMo })+0.112(\mathrm{ACr} / \mathrm{ACo})+0.118(\mathrm{PMAr} / \mathrm{PMAo})+0.101 \\
(\mathrm{Mr} / \mathrm{Mo})+0.270(\mathrm{DLr} / \mathrm{DLo})+0.260(\mathrm{Ir} / \mathrm{Io})
\end{gathered}
$$

The calculated values of $\mathrm{K}$ in the execution period are shown in Table 1:

Table 1. $\mathrm{K}$ values of Case 1 obtained with the current formula.

\begin{tabular}{|c|c|c|c|c|c|c|c|c|c|}
\hline oct-16 & nov-16 & dic-16 & ene-17 & feb-17 & mar-17 & abr-17 & may-17 & jun-17 & jun-17 \\
\hline 1,01 & 1,016 & 1,016 & 1,014 & 1,01 & 1,016 & 1,013 & 1,016 & 1,014 & 1,013 \\
\hline
\end{tabular}

\section{Case 2:}

Its polynomial formula is:

$$
\begin{gathered}
K=0.066 A M r / A M o+0.138 A C r / A C o+0.117 \mathrm{Mr} / \mathrm{Mo}+0.082 \mathrm{Jr} / \mathrm{Jo}+0.285 \mathrm{Dr} / \mathrm{Do}+0.121 \\
A r / A o+0.191 \mathrm{GGUr} / \mathrm{GGUo}
\end{gathered}
$$

The calculated values of $\mathrm{K}$ in the execution period are shown in Table 2:

Table 2. $\mathrm{K}$ values for Case 2 obtained by the current polynomial formula.

\begin{tabular}{|c|c|c|c|c|c|c|c|c|c|}
\hline may-13 & jun-13 & jul-13 & ago-13 & sep-13 & oct-13 & nov-13 & dic-13 & ene-14 & feb-14 \\
\hline 0,995 & 1,012 & 1,026 & 1,031 & 1,029 & 1,026 & 1,03 & 1,028 & 1,033 & 1,035 \\
\hline
\end{tabular}

\section{Correlational analysis in the pretest}

The correlational analysis of $\mathrm{K}$ in figure $\mathrm{x}$. a) shows the graphic of the correlation

$$
y=-4 E-05 x 4+0.0008 x 3-0.0061 \times 2+0.018 x+0.9978, \text { and } R^{2}=0.5102
$$

The correlational analysis of $\mathrm{K}$ in figure $\mathrm{x} . \mathrm{b}$ ) shows the graphic of the correlation

$$
y=0.015 \ln (x)+1.0018 \text { and } R^{2}=0.8303
$$


In Table 3, the consolidated values of both cases are shown:

Table 3. K values calculated with the current polynomial formula.

\begin{tabular}{|c|c|c|}
\hline $\mathbf{N}^{\mathbf{a}}$ & Vinic Case 1 & Vinic Case 2 \\
\hline 1 & 1,010000000 & 0,99500000 \\
\hline 2 & 1,016000000 & 1,01200000 \\
\hline 3 & 1,016000000 & 1,02600000 \\
\hline 4 & 1,014000000 & 1,03100000 \\
\hline 5 & 1,010000000 & 1,02900000 \\
\hline 6 & 1,016000000 & 1,02600000 \\
\hline $\mathbf{8}$ & 1,013000000 & 1,03000000 \\
\hline $\mathbf{9}$ & 1,016000000 & 1,02800000 \\
\hline 10 & 1,014000000 & 1,03300000 \\
\hline
\end{tabular}

Source: own elaboration.

\section{Correlational analysis of the experimental group in the pre-test}

The results of the correlational analysis are shown in Figures 2 with the comparison of the $\mathrm{K}$ values with the methods used in cases 1 and 2 and the respective distribution of differences in $\mathrm{K}$ values.

Correlational analysis in the pre-test of the K Vinic values case 1 and case 2.

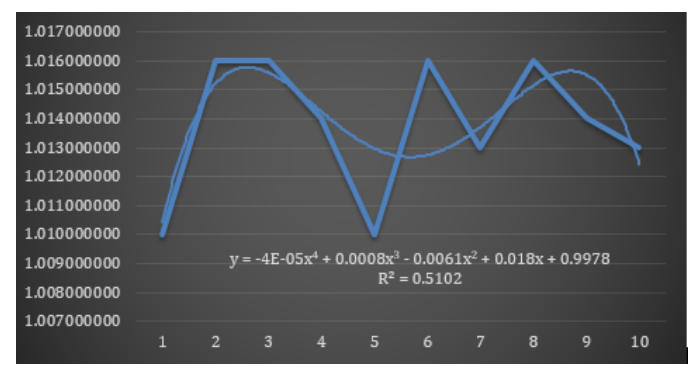

(a)

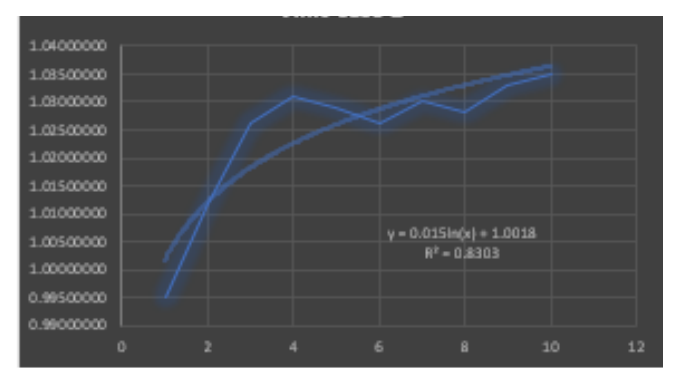

(b)

Figure 2. Correlational analysis of $\mathrm{K}$ values a) Vinic case 1 and b) Vinic case 2. 


\section{Correlational analysis of the experimental group in the post-test}

The results of the correlational analysis post-test are shown in Figure 3 with the comparison of the K values. Figure 4 shows correlation with the methods used in for cases 1 and 2.

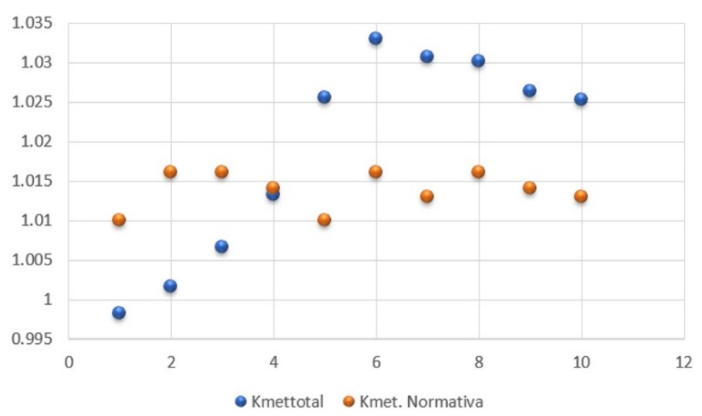

(a)

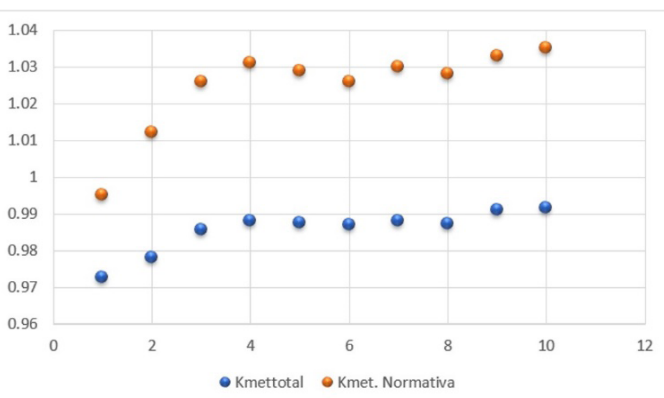

(b)

Figure 3. Comparison between $\mathrm{K}$ values using the two methods, a) case 1 and $\mathrm{b}$ ) case 2 .

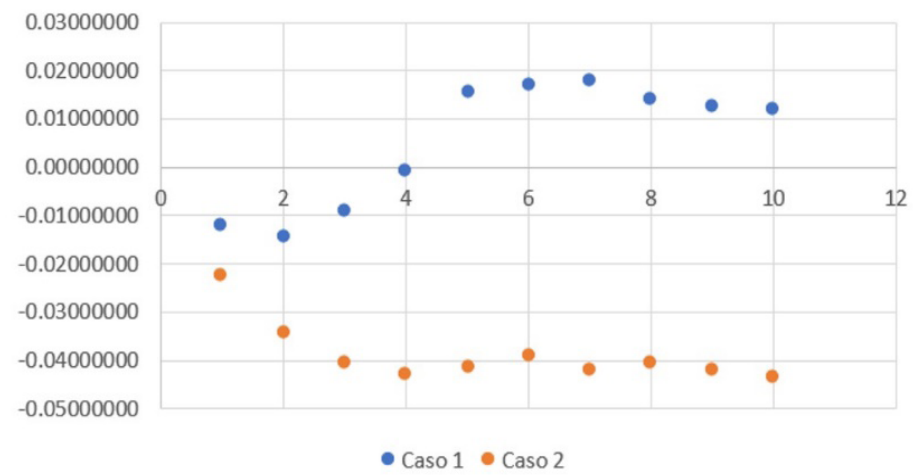

Figure 4. Distribution of differences in $\mathrm{K}$ values in cases 1 and 2.

\section{DISCUSSION}

With the information has been verified that, in all cases, there is a difference of $\mathrm{K}$ more significant than $0.1 \%$, It has been established as a maximum allowed value of $0.1 \%$ since, with current regulations, 
$\mathrm{K}$ values are rounded to the thousandth, with which any variation above $0.1 \%$ will produce different readjustments.

In road works contracts, there are monthly valuations that on average exceed one million soles, which means that variations above the $0.1 \%$ threshold implied that the readjustments that have been paid were different from those corresponding

According to the graphs that have been shown, where you can see, the differences are negative, which means that the readjustments that have been paid have been more than they were due to the contractors.

\section{CONCLUSION}

The $\mathrm{K}$ values obtained, using all the inputs, with a reliability of $95 \%$, are less than those resulting from the current polynomial formula, the difference in these values reaches a maximum of -0.043 , which means a difference, with regarding the floor value of 0.001 , of $4,300 \%$ difference, that in terms of money, in a monthly valuation with a minimum positive difference, however, if the contracting of works is considered, annually for more than 10 billion, the approximate value of $\mathrm{S} / .430$ '000,000.00 where the mean of the difference for case 2 corresponds to 0.039 .

Likewise, the polynomial formula established by current regulations does not reflect the correct variation in input prices and to determine the $\mathrm{K}$ value, all the inputs that intervene in the road works budget must be used, so the polynomial formula should be stated as:

$$
K=\sum_{\mathrm{i}=1}^{n} A i \frac{I r i}{I o i}
$$

Where:

$\mathrm{n}=$ The total amount of inputs from the works budget

$\mathrm{A}=$ The incidence of $\mathrm{i}$ resulting from the value of the input between the total value of the budget minus taxes 
Iri $=$ The unified index of $\mathrm{i}$ one month after recovery

Ioi $=$ The unified index of $\mathrm{i}$ per month of the reference value

\section{REFERENCES}

Huapaya, H. D., Rodriguez, C., \& Esenarro, D. (2020). Comparative analysis of supervised machine learning algorithms for heart disease detection. 3C Tecnología. Glosas de innovación aplicadas a la pyme. Edición Especial, Abril 2020, 233-247. http://doi.org/10.17993/3ctecno.2020. specialissue 5.233-247

Levy,J., Pandey, B., Ghowdhry, B. S., \& Rodriguez, C. (2020). Prologue: Recent trends in computer science and engineering (RTCSE). 3C Tecnología. Glosas de innovación aplicadas a la pyme. Edición Especial, Abril 2020, 19-25. http://doi.org/10.17993/3ctecno.2020.specialissue5.19-25

Ministry of Transport. (2015). Statistical Yearbook 2015. Solyani.

Muñoz, D. R. (2004). Manual de estadística. Eumed.net. https://www.researchgate.net/profile/ David_Ruiz-Munoz/publication/267829008_Manual_de_Estadistica_Manual/ links/5821b19708ae5385869fdb6e/Manual-de-Estadistica-Manual.pdf

Navarro, J. D. (2017, March 22). Matemáticas financieras. Valor del dinero en el tiempo. ABCfinanzas.com. https://www.abcfinanzas.com/matematicas-financieras/valor-del-dinero-en-el-tiempo

Sánchez, J., Vega, H., Guzmán, Y., Rodriguez, C., \& Quinto, D. (2020). Data mart design to improve the decision-making process of the after-sales service. Test Engineering and Management, 83, 15481-15494. http://www.testmagzine.biz/index.php/testmagzine/article/view/6539

Soto, B., Vega, H., Guzmán, Y., Rodriguez, G., \& Quinto, D. (2020). Classification algorithm based on machine learning to optimize athletes talent detection. Test Engineering, 83, 13464-13471. http://www.testmagzine.biz/index.php/testmagzine/article/view/6067 
